\title{
Influences of the Free Trade Agreement between South Africa and the European Union on the South African Fresh Orange Industry
}

\author{
S H Gay and W L Nieuwoudt'
}

University of Natal, Pietermaritzburg

\section{ABSTRACT}

This paper evaluates the effects of the Free Trade Agreement (FTA) between South Africa and the European Union (EU) on the South African orange industry. Oranges account for ten percent of South African agricultural exports. The aggregate trade simulation model used here is designed on the programme STELLA, and consists of regional production models, a local market model, an export model and an exchange rate model. Results indicate that the FTA is expected to have small positive effects on both South African producers and consumers. This is caused by increasing real free-on-board prices and decreasing real local prices of oranges. Total area under oranges will increase more with the FTA, which thus results in a larger orange production too.

JEL Q13

\section{INTRODUCTION}

In October 1999 South Africa and the European Union (EU) signed the Trade, Development and Co-operation Agreement. A major part of this agreement is the establishment of a free trade area between both parties, a Free Trade Agreement (FTA). As the EU is the major trading partner of South Africa, this will have an important impact on the South African fruit sector which is the major export in the field of agriculture. Within this sector oranges play a vital role. Oranges alone account for approximately ten percent of all agricultural exports of South Africa while 60 percent of all oranges are exported. The proportion exported is constraint by sanitary and phyto-sanitary requirements of the destinations. The majority of the remainder is processed, leaving less than 20 percent for the local fresh produce market. After a small dip in importance in the early and mid nineties the EU presently accounts for the destination of almost two thirds of all exported oranges. This paper evaluates the effects of the FTA with the EU on the South A frican fresh orange industry. A trade simulation model is constructed to simulate future developments. 


\section{TRADE SIMULATION MODEL}

The trade simulation model is developed on a graphical interface using the programme STELLA to indicate linkages between different variables (High Performance Systems, 1997). In the model it is possible to use stochastic distributions or random figures to quantify relationships. This has been done if the distribution is known or could be estimated. Each scenario is run 100 times and results are statistically analysed. The trade simulation model consists of several linked sub-models. These include seven production models, a local market model, an exchange rate model and a model for the EU demand. The submodels will be discussed.

\subsection{Production Models}

The production of fresh oranges occurs mainly in the following four regions within South Africa: the Lowveld region of the Northern Province and Mpumalanga, the North-West Province, the Sundays River region of the Eastern Cape, and the Olifants River region in the Western Cape. The two main cultivar groups are Navels and Valencias, each with different ripening seasons. As Navels are not planted in the Lowveld region, seven production models are included for regions and cultivar group. Gross margins, cost and production data were used to derive the age of the orchard (Ferreira and van Zyl, 1997). The gross margins are based on cross-sectional data of the year 1995. Information provided by Bower (1999) is used to derive a seasonal production distribution within each production model. The supply response is simulated through planting new orchards while it is not possible to withdraw orchards before the end of the productive life-span. Equation (1) shows the supply response.

$$
\ln p l_{t}^{r g}=\beta_{0}^{r z g}+\varepsilon_{s}^{*} \ln \frac{t o t r}{c_{r}^{r q z g}}
$$

\section{Where:}

In = Natural logarithm

$p l \quad=$ Plantings of new orange orchards

$\varepsilon_{\mathrm{s}} \quad=$ Elasticity of supply

to $=$ Total orange turnover

c = Variable costs

reg = Production region (cultivar and locality)

$t=$ Year.

However, own estimates for a supply elasticity could not be derived because of lack of information about annual increase in acreage. Khuele and Darroch (1997) estimate the export supply elasticity for South African oranges to the United Kingdom at 0.248 . This estimate refers to production rather than orange growing area and it excludes the supply to other destinations, as well as the local 
market. Further, a supply elasticity of 0.128 for perennial products in Italy has been obtained by Sckokai and Moro (1996) which is of a similar magnitude. Approximately five to ten percent of total area is annually replanted or freshly planted. Therefore, a supply elasticity in terms of area planted every year should be ten to twenty times as large, implying a supply elasticity of approximately 2.0 for planting.

\subsection{Local Market}

About 40 percent of the South African orange production is either processed or sold locally. This section analyses the proportion sold on the local fresh produce markets. The monthly real prices at the four main South African fresh produce markets for oranges - Johannesburg, Pretoria, Durban and Cape Town - are analysed to obtain a local demand function. An influential variable is the actual amount sold in a particular month. The lagged export price influences the local price, due to the linkage between both markets. A trend variable is included in the model to capture the change in consumer preferences over time, especially towards easy-peelers. Ordinary least square (OLS) is used to estimate the demand function (2) (t-values in parentheses).

$$
\begin{aligned}
& \ln \frac{p r_{t}^{*} 100}{c p i_{t}}=4.311-0.301 * \ln \frac{q_{t}}{p o p}+0.216 * \ln \frac{p r_{t-1}^{* x} * e x_{t-1}^{*} 100}{c p i_{t-1}}-0.0036 * \text { trend }_{t} \\
& \text { (8.9) }(-16.9) \\
& F \text {-value }=97.5
\end{aligned}
$$

Where:

In = Natural logarithm

$\mathrm{pr} \quad$ = Nominal monthly price for fresh oranges on South African fresh produce markets (R/ton)

$c p i=$ Consumer price index in South Africa $(1990=100)$

$q \quad=$ Total monthly fresh orange quantity traded on South African fresh produce markets (tons)

pop = Total South African population ( ${ }^{\circ} 000$ )

$p r^{e x}=$ Entry price for fresh oranges in the European Union (ECU/ton)

$e x \quad=$ Exchange rate $(\mathrm{R} / \mathrm{ECU})$

trend $=$ Monthly trend variable (January $1990=1$ )

$t=1, \ldots, 96$ months (January 1990 until December 1997)

Signs of all variables are as expected. The Durbin-Watson test for autocorrelation is not reported because of missing values. The price flexibility of demand, approximately an inverse of the price elasticity, in the local market is estimated at -0.301 which is lower than the -0.695 obtained by Hayward-Butt and Ortmann (1994). This is expected as short term demand elasticities are 
generally larger than demand elasticities based on annual data due to the possibility of short term storage (Shepherd, 1972: 67-68).

\subsection{Exchange rate between South African Rand and Euro}

The exchange rate between the South African Rand and the Euro is important for a trade model. South African producers are interested in the Rand price received for their product, whereas consumers in the EU pay in Euro. The Euro has a fixed exchange rate to eleven European currencies which will be replaced by the Euro in 2002. It was introduced in January 1999 as a single currency in eleven EU member countries to replace the ECU (European Currency Unit). The exchange rate between the Rand and ECU is analysed from 1990 until 1996 to obtain a predictive function for the future exchange rate. In this study the EU market is represented by Germany because of lack of information about the EU monetary market prior to 1999. Monetary models are based on the assumption of purchasing power parity. This was tested using the Cochrane-Orcutt two step procedure (3) (t-values in parenthesis).

(3) $\ln e x_{t}-\rho^{*} \ln e x_{t-1}=1.395^{*}\left(\ln C P I_{t}^{S A}-\rho^{*} \ln C P I_{t-1}^{5 A}\right)-1.179^{*}\left(\ln C P I_{t}^{\text {Ger }}-\rho^{*} \ln C P I_{t-1}^{\text {Ger }}\right)$

$$
\text { F-value }=411.4 \quad \text { adjusted } \mathrm{R}^{2}=0.91 d=1.57
$$

Where:

$$
\begin{array}{ll}
\ln & =\text { Natural logarithm } \\
e x & =\text { Exchange rate }(\mathrm{R} / \mathrm{ECU}) \\
C P I & =\text { Consumer price index }(1990=100) \\
\mathrm{SA} & =\text { South Africa } \\
\text { Ger } & =\text { Germany } \\
\rho \quad & =0.961 \text { coefficient of autocorrelation (Cochane-Orcutt two-step) } \\
t & =1, \ldots, 84 \text { month (January } 1990 \text { until December 1996) }
\end{array}
$$

The coefficients have the expected signs. If the South African price level increases, the Rand depreciates against the Euro. The opposite is the case for the German price level. The statistical fit is excellent and results are in accordance with theoretical economic expectations. The purchasing power parity model is used to predict future exchange rates in the trade simulation model. As the simulation period starts in 1997 the results of the first three years can be compared with the actual exchange rate (Figure 1). In the first part of 1997 the actual exchange rate was below the 95 percent confidence interval, but thereafter the exchange rate stayed within the interval. This even includes the period of rapid change in July 1998. 


\section{Figure 1 Predicted and actual exchange rate between Rand and Euro 1997 until 1999}

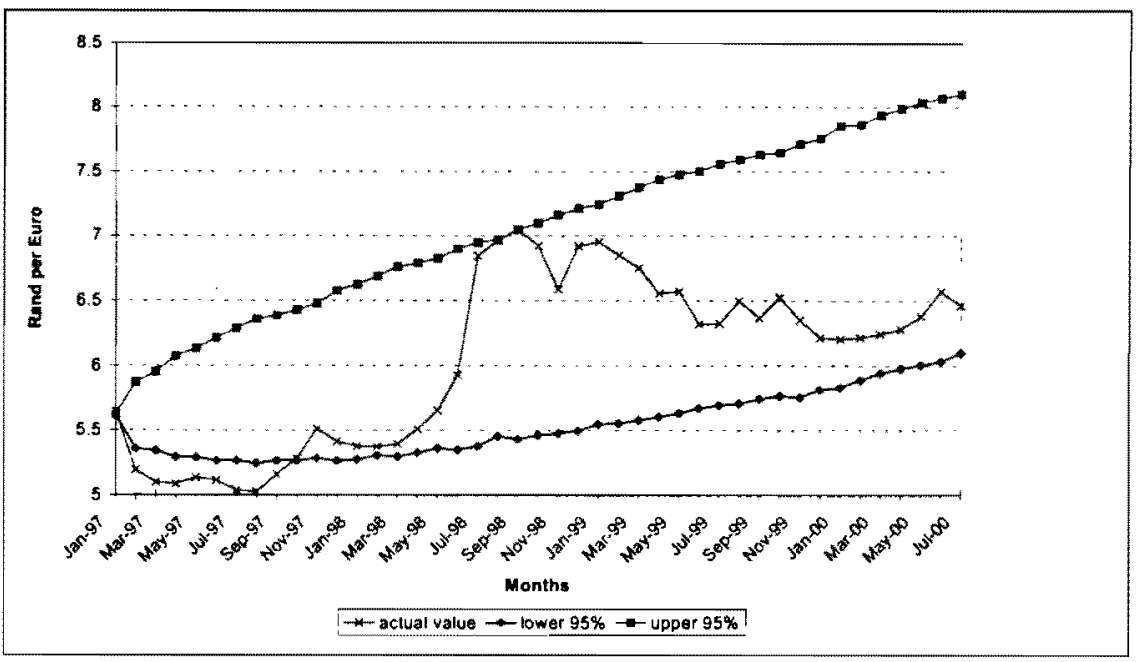

Source: De Nederlandsche Bank (2000) and own calculations

Macro-economic indicators included in the model are Consumer Price Index (CPI) on both sides, and Producer Price Index (PPI) and population only on the South African side. The German CPI is expected to change according to the behaviour in the base period from 1990 until 1996. The South African CPI is expected to have decreasing rates of increase (Nedcor, 1999). It is expected to decline from around seven percent in 1997 to five percent in 2011. The PPI is derived from the CPI in the model based on their historic relationship. The population in South Africa is expected to increase at a decreasing rate. Population predictions by Sadie (1993) were used to design a population growth model for South Africa.

\subsection{European Market}

The European Union (EU) is the largest export market for South African fresh oranges. In the early and mid-nineties the EU share of South African exports has been declining, but it still accounted for 50 percent of total South African exports. Recently, it increased again to almost two thirds. South Africa is the second largest external supplier of oranges to the EU (Table 1). 
Table 1 External imports of oranges by the European Union in metric tons

\begin{tabular}{|c|c|c|c|c|c|c|}
\hline & 1991 & 1992 & 1993 & 1994 & 1995 & 1996 \\
\hline Morocco & 349947 & 289287 & 254739 & 248181 & 172684 & 315971 \\
\hline $\begin{array}{l}\text { South } \\
\text { Africa }\end{array}$ & 161510 & 175405 & 135007 & 178552 & 167283 & 228365 \\
\hline Israel & 95076 & 98093 & 72746 & 53887 & 93402 & 115247 \\
\hline Brazil & 72454 & 62107 & 67269 & 90743 & 81063 & 69880 \\
\hline Argentina & 71891 & 63997 & 52987 & 66961 & 65423 & 68043 \\
\hline Uruguay & 32406 & 44694 & 57062 & 52389 & 49740 & 34819 \\
\hline Turkey & 10896 & 6469 & 5185 & 8630 & 24268 & 30911 \\
\hline Cuba & 17200 & 17266 & 22845 & 22166 & 21027 & 22705 \\
\hline Cyprus & 43764 & 59170 & 38374 & 42177 & 36410 & 20781 \\
\hline Tunisia & 20927 & 19190 & 20097 & 20356 & 22620 & 20162 \\
\hline Zimbabwe & 6643 & 5626 & 3019 & 6325 & 5799 & 13067 \\
\hline Extra-EU & 922925 & 885543 & 798112 & 846627 & 869659 & 967499 \\
\hline
\end{tabular}

Source: Eurostat

Due to its location in the Southern hemisphere, South Africa dominates the EU off-season. South Africa is generally a price taker on the European market but during the months of July until October South Africa can influence EU prices significantly. During the later months oranges originated in South Africa account for two thirds of the EU market. For the other months the price of fresh oranges in the EU are seen as exogenous variables. The average real price of the years 1991 until 1996 (1990 prices) is taken as the baseline price and the generated price within the model. During the months of July until October a monthly price flexibility is calculated of the import demand fo. South African oranges. The following procedure was used. Firstly an annual price flexibility for oranges in Germany is calculated. Germany is chosen because it is the main EU market and because of the availability of data. As independent variables, the income and the orange consumption per capita and a dummy variable for German unification are used. The resulting price flexibility is -0.479 . This price flexibility calculated using data for Germany was assumed to be a proxy for that of the EU in the model. Secondly, monthly price flexibilities of the import demand for South African oranges are calculated in (4), using a procedure adapted from Johnson (1971).

$$
\rho_{S 4}=\frac{X}{D} * \rho-\frac{X}{S} * \frac{I}{\varepsilon}
$$

Where:

$\rho_{\mathrm{SA}}=$ Import demand flexibility for South African oranges in the EU

$\rho \quad=$ Demand flexibility for oranges in the EU 
$D=$ Total quantity of oranges demanded in the EU (metric tons)

$X \quad=$ South African exports of oranges to the EU (metric tons)

$\varepsilon \quad=0.2$ (supply elasticity of rest of the world to the EU market)

$S \quad=$ Quantity supplied by the rest of the world to the EU market (metric tons)

The supply elasticity of the rest of the World on the EU market is derived from information from Sckokai and Moro (1996) for the Italian market. The simulated monthly prices for fresh oranges in the EU are then transformed into free-onboard prices in South Africa in Euro. This is achieved by firstly deducting the tariff. In the months June to November a division by one plus the ad valorem tariff is carried out. For the rest of the year the entry price system in the EU is in force (Swinbank and Ritson, 1995). Therefore, it has to be determined whether the entry price before tariffication is below the threshold. If this is the case, a tariff equilibrium has to be subtracted as well. If not, the same process is used as for the other months. In all months, the cost of transport from the South African harbour to the EU point of entry has to be deducted. The transport costs are expected to stay constant in nominal terms at 150 Euro per ton over the time of simulation. The 150 Euro per ton derives from the difference in South African prices in the harbour and the EU between 1991 and 1996. Information from FAO (1994) implies constant nominal transport costs for wheat in United States Dollars which is assumed to be the case $r$ oranges in Euro. To retain the prices in Rand at the South African harbou: the Euro value is multiplied by the predicted exchange rate.

\section{FUTURE SCENARIOS}

This paper compares the future prospects of the South African fresh orange industry under the FTA to a base scenario without the FTA. The Base scenario will use the current EU tariffs and the commitment the EU has submitted to the World Trade Organization (WTO). The FTA scenario will use the same tariffs, but it will in addition use the outcome of the FTA. Table 2 shows tariffs in the EU and inclusion in the FTA of fresh oranges in relation to date of entry. 
Table 2 European Union tariffs for fresh sweet oranges in 1999 and FTA treatment

\begin{tabular}{|l|c|c|c|}
\hline \multicolumn{1}{|c|}{ Period } & $\begin{array}{c}\text { Tariff 1999 in } \\
\text { percent }\end{array}$ & Entry price & FTA treatment \\
\hline 1 January to 31 March & 17.3 & Yes & excluded \\
\hline 1 to 30 April & 11.3 & Yes & excluded \\
\hline 1 to 15 May & 5.2 & Yes & excluded \\
\hline 16 to 31 May & 3.5 & Yes & excluded \\
\hline 1 June to 30 September & 3.5 & No & included \\
\hline 1 to 15 October & 3.3 & No & excluded \\
\hline 16 October to 30 November & 16.7 & No & excluded \\
\hline 1 to 31 December & 16.7 & Yes & excluded \\
\hline
\end{tabular}

Source: Hauptzollamt Kiel (1999) and Department of Trade and Industry (1999)

The entry price system means that an additional tariff equivalent is charged if the entry price before tariffs falls short of the threshold price. The inclusion in the FTA will only occur at a later stage of the implementation period from 2000 until 2011. The included time period accounts for the majority of South African fresh orange exports to the EU. The tariff for South African fresh sweet oranges in the peak exporting season will be eliminated within the FTA. This could have an impact on the South A frican fresh orange industry.

The simulation period covers from 1997 until 2011, hence fifteen years. The final year is set by the end of the implementation period of the FTA between South Africa and the EU. Each scenario is run 100 times and results are analysed. Mean and standard deviation values are also reported.

\section{RESULTS}

The impacts on both South African producers, as well as consumers are studied. In addition changes in the exchange rate and prices are reported.

\subsection{Exchange rate and orange prices}

No difference in the predicted exchange rate is expected between the scenarios as there is no interaction between the tariffs and the exchange rate within this model. Table 3 presents the simulated annual exchange rate. 
Table 3 Predicted exchange rate between Rand and Euro 1997 until 2011 in Rand

\begin{tabular}{|l|c|c|c|c|c|c|c|c|}
\hline & $\mathbf{1 9 9 7}$ & $\mathbf{1 9 9 9}$ & $\mathbf{2 0 0 1}$ & $\mathbf{2 0 0 3}$ & $\mathbf{2 0 0 5}$ & $\mathbf{2 0 0 7}$ & $\mathbf{2 0 0 9}$ & $\mathbf{2 0 1 1}$ \\
\hline Upper limit (95\%) & 6.10 & 7.42 & 8.57 & 9.49 & 10.66 & 11.89 & 13.08 & 14.37 \\
\hline Lower limit (95\%) & 5.40 & 5.74 & 6.42 & 7.43 & 8.31 & 9.12 & 10.00 & 11.17 \\
\hline
\end{tabular}

In section 2.3. the results for 1997 until 2000 are compared with the actual exchange rate.

The local South African orange price is predicted to increase at less than the inflation rate. Therefore the real prices for fresh oranges in South Africa are predicted to decline. This is comparable with the local price development in recent years. Table 4 indicates the mean predicted prices for fresh oranges at the fresh produce markets in South Africa.

Table 4 Predicted mean real prices for fresh oranges on the fresh produce markets in South Africa 1997, 2004 and 2011 in Rand (1997) per metric ton

\begin{tabular}{|l|c|c|c|c|c|c|}
\hline & \multicolumn{3}{|c|}{ Base Scenario } & \multicolumn{3}{c|}{ Free Trade Agreement } \\
\hline & $\mathbf{1 9 9 7}$ & $\mathbf{2 0 0 4}$ & $\mathbf{2 0 1 1}$ & $\mathbf{1 9 9 7}$ & $\mathbf{2 0 0 4}$ & $\mathbf{2 0 1 1}$ \\
\hline January & 1956 & 1456 & 1144 & 1937 & 1460 & 1141 \\
\hline February & 1637 & 1229 & 1015 & 1677 & 1262 & 995 \\
\hline March & 1148 & 911 & 732 & 1177 & 901 & 703 \\
\hline April & 888 & 703 & 556 & 888 & 700 & 538 \\
\hline May & 677 & 530 & 418 & 667 & 538 & 411 \\
\hline June & 601 & 470 & 371 & 602 & 480 & 374 \\
\hline July & 597 & 443 & 344 & 578 & 444 & 348 \\
\hline August & 591 & 446 & 355 & 588 & 457 & 352 \\
\hline September & 663 & 498 & 390 & 646 & 504 & 387 \\
\hline October & 918 & 687 & 535 & 902 & 700 & 540 \\
\hline November & 1212 & 906 & 722 & 1205 & 921 & 696 \\
\hline December & 1590 & 1206 & 934 & 1542 & 1195 & 917 \\
\hline
\end{tabular}

The means values of both scenarios are similar. A coefficient of variation of 10 to 15 percent was observed which implies that there is no significant difference between the scenarios. The estimates show a strong seasonality in the local South African market with low prices in the middle of the year which is the peak production season in South Africa. 
An important result is the difference between domestic and international prices for fresh oranges. Table 5 presents the free-on-board prices at the point of departure. The real free-on-board prices are predicted to increase during the simulation period. A difference between both scenarios cannot be observed despite a tariff reduction of approximately two percent from June until September. Due to increased South African exports in this period, the EU prices decline slightly. This results in constant free-on-board prices in South Africa.

Table 5 Predicted mean real free-on-board prices for fresh oranges in South African ports 1997, 2004 and 2011 in Rand (1997) per metric ton

\begin{tabular}{|l|c|c|c|c|c|c|}
\hline & \multicolumn{3}{|c|}{ Base Scenario } & \multicolumn{3}{c|}{ Free Trade Agreement } \\
\hline & $\mathbf{1 9 9 7}$ & $\mathbf{2 0 0 4}$ & $\mathbf{2 0 1 1}$ & $\mathbf{1 9 9 7}$ & $\mathbf{2 0 0 4}$ & $\mathbf{2 0 1 1}$ \\
\hline January & 881 & 1535 & 1990 & 993 & 1634 & 1946 \\
\hline February & 779 & 1387 & 1833 & 843 & 1339 & 1774 \\
\hline March & 1002 & 1616 & 2064 & 1029 & 1603 & 1906 \\
\hline April & 1271 & 1782 & 2120 & 1131 & 1817 & 2124 \\
\hline May & 1410 & 1896 & 2297 & 1332 & 1876 & 2212 \\
\hline June & 1576 & 1855 & 2119 & 1590 & 1815 & 2084 \\
\hline July & 1447 & 1747 & 1923 & 1490 & 1739 & 2054 \\
\hline August & 1572 & 1812 & 1952 & 1552 & 1830 & 1974 \\
\hline September & 1707 & 1990 & 2243 & 1727 & 2038 & 2251 \\
\hline October & 1425 & 1555 & 1949 & 1353 & 1631 & 1850 \\
\hline November & 1619 & 1962 & 2487 & 1499 & 2026 & 2298 \\
\hline December & 1101 & 1647 & 2055 & 989 & 1636 & 1973 \\
\hline
\end{tabular}

In the EU seasun the free-on-board prices are especially low in the first years of the simulation period. One reason is the EU entry price system. An additional levy will be charged if the entry price falls under a certain threshold. Due to WTO commitments the threshold price also has to be reduced. Therefore, the additional levy will be charged less often and the average free-on-board price will increase. The change in the exchange rate between Rand and Euro is the major cause for the increasing free-on-board price in South Africa.

There is no difference between both scenarios with regards to the free-on-board prices in South Africa. Even so, an increase of three percent in the months June until September is expected because of the tariff cut over these months. This is caused by an slight increase in South African exports to the EU, which has a slight reducing impact on the EU prices. The observed price difference between the months is lower than on the fresh produce markets. There is a slight increase towards the middle of the year, but otherwise the prices are relatively constant. 
The predominant observation in relation to real prices is the increasing difference between local and free-on-board prices (Table 4 and 5). This observation can also be made for the current decade. This result implies that the export orientation of producers will increase in the coming years. Bower (1999) however, expects that the export percentage will not change much in the future because of samitary and phyto-sanitary requirements becoming more stringent.

\subsection{Orange production and area under oranges}

The analysis of the simulated development of the South African fresh orange production will be undertaken on an area, as well as on a production basis. The area used in this study was derived from total production and the yield information based on the gross margins of Ferreira and van Zyl (1997). Therefore, only changes expressed in percentage terms, are used in the analysis. These percentages refer to well managed and high production orchards. Table 6 shows the change in acreage in the seven production regions.

Table 6 Percentage change in total area planted with oranges by production region

\begin{tabular}{|c|c|c|c|c|c|}
\hline & \multicolumn{2}{|c|}{ Base scenario } & \multicolumn{2}{|c|}{ Free Trade Agreement } \\
\hline Region & Cultivar & $1997-2004$ & $1997-2011$ & $1997-2004$ & $1997-2011$ \\
\hline Lowveld & Valencias & $3.75 \%$ & $10.04 \%$ & $4.75 \%$ & $12.00 \%$ \\
\hline \multirow[t]{2}{*}{ North-West } & Navels & $-5.87 \%$ & $-6.61 \%$ & $-5.35 \%$ & $-5.46 \%$ \\
\hline & Valenci & $3.96 \%$ & $10.55 \%$ & $5.01 \%$ & $12.57 \%$ \\
\hline \multirow{2}{*}{\begin{tabular}{|l} 
Sundays \\
River
\end{tabular}} & Navels & $-4.16 \%$ & $-7.86 \%$ & $-3.61 \%$ & $-6.68 \%$ \\
\hline & Valencias & $4.96 \%$ & $15.28 \%$ & $5.44 \%$ & $16.49 \%$ \\
\hline \multirow{2}{*}{\begin{tabular}{|c|} 
Olifants \\
River
\end{tabular}} & Navels & $-4.93 \%$ & $-9.60 \%$ & $-4.24 \%$ & $-8.21 \%$ \\
\hline & Valenci & $4.42 \%$ & $14.56 \%$ & $4.71 \%$ & $15.60 \%$ \\
\hline Total & & $-0.07 \%$ & $2.42 \%$ & $0.68 \%$ & $3.97 \%$ \\
\hline
\end{tabular}

The base scenario shows that there is a small overall increase in area planted with oranges at the end of the simulation period (Table 6). The predominant result is the decrease of Navel plantings. The area under Valencias has increased by over ten percent in the simulation period. The difference between the development of Navel and Valencia orchards could also be observed in previous years (AgriReview, 1999). The FTA scenario indicates that there will be a further increase in orange production area due to the FTA. This is not significant due to the high variability of results, but is consistent throughout the results. Because of the long life span of orange orchards, even a 15 year period seems to be too short to observe significant differences. The problem in observing significant differences lies in the high variability of additional factors 
influencing the production of perennial export crops. These are weather conditions, price fluctuations on local and overseas market and fluctuating exchange rates.

The total orange production increases in the first five years of the simulation by approximately nine percent. This can be explained by an increased percentage of mature trees. Thereafter, the changes are small as expected by the increase in area under oranges. The total increase during the simulation period under the base scenario is 9.11 percent and 10.48 percent in the case of the FTA scenario. In this analysis is expected that the change in supply is borne by a change in acreage. It is very likely that in the short run, South African exports are diverted towards the EU from other export markets as the EU becomes relatively more profitable as an export destination. This is limited by the extent of the tariff reduction and the export commitment of producers. In the long run an adjustment will happen on the production side.

\subsection{Gross margins and consumer surplus}

Gross margins are a good indicator for the development of the profitability of orange production. Table 7 shows the development of gross margins in the seven production regions.

Table 7 Predicted percentage change in real gross margins by production region

\begin{tabular}{|c|c|c|c|c|c|}
\hline & & Base so & enario & Free Trade & Agreement \\
\hline Region & Cultivar & $1997-2004$ & $1997-2011$ & $1997-2004$ & $1997-2011$ \\
\hline Lowveld & Valencias & $52.61 \%$ & $85.79 \%$ & $56.72 \%$ & $93.33 \%$ \\
\hline North-West & Navels & $32.16 \%$ & $53.76 \%$ & $36.39 \%$ & $55.55 \%$ \\
\hline & Valencias & $42.91 \%$ & $78.14 \%$ & $49.19 \%$ & $85.60 \%$ \\
\hline Sundays & Navels & $35.82 \%$ & $51.18 \%$ & $51.60 \%$ & $61.10 \%$ \\
\hline River & Valencias & $40.50 \%$ & $90.37 \%$ & $51.54 \%$ & $94.69 \%$ \\
\hline Olifants & Navels & $45.56 \%$ & $58.62 \%$ & $51.45 \%$ & $67.75 \%$ \\
\hline River & Valencias & $52.96 \%$ & $100.65 \%$ & $68.00 \%$ & $109.19 \%$ \\
\hline Total & & $45.54 \%$ & $75.17 \%$ & $52.84 \%$ & $82.42 \%$ \\
\hline
\end{tabular}

Real gross margins are increasing dramatically in all regions. This is due to an increase in free-on-board prices and to increased production. Even for the regions planted with Navels an strong increase in real gross margins could be observed. In the later years of the simulation the difference between Navels and Valencias increases. The FTA scenario is more beneficial in relation to real gross margins. It is consistent within all results but not statistically significant. 
On the domestic consumer side the development of consumer surplus is of interest. The real consumer surplus increases over the simulated period by approximately 50 percent. It is two percent higher in the FTA scenario in the final years. This indicates that the local consumer benefits slightly from the FTA with the EU.

\section{CONCLUSIONS}

The results indicate that the FTA has a slightly beneficial effect for South African orange producers and domestic consumers. Due to the high volatility of other influential factors, such as weather conditions, the exchange rate, and quality variation, these results are not statistical significant. The consistency of the results makes it very likely that a positive effect exists. The larger observed increase in acreage under the FTA might result in a larger difference in production over time. Due to the time delay between planting and maturity this will only occur later. A longer simulation period could be useful to obtain such results but this is limited by the assumptions about the orange industry underlying the development of the model.

The observed and significant difference in the future development of area under Navels and Valencias is consistent with recent observations (AgriReview, 1999). A total change from Navels towards Valencias seems to be unlikely. Both cultivars have different ripening seasons which is beneficial for a more distributed utilisation of the labour force and packhouses. For the industry as a whole a longer production period is advantageous to be present on export markets. This is especially necessary for branding and advertising.

The FTA is a win-win situation for South Africa because both domestic producers and consumers are expected to benefit from the agreement. This is due to the contrary development of domestic and free-on-board prices. The domestic consumer benefits from lower real local prices. South African domestic prices are expected to fall as South African production increases as a constant percentage of South African production does not meet export requirements. Whereas, this is more than offset by the increase in real free-onboard prices for the local producers. The effect in the EU will be limited. South African exports are expected to increase overall by ten percent over the fifteen year simulation period, whereof one percent is due to the FTA. The increased South African exports are expected to result in a small decrease of orange prices in the EU summer. This will have a very small impact on EU producers as that is their off-season. 
A small difference between both scenarios was expected a priori because the tariff cut for fresh oranges agreed upon in the FTA is small. The EU will eliminate the tariffs from June until September which are currently three percent ad valorem. A comparison with a scenario eliminating all EU tariffs on fresh oranges will result in information about the impact EU protection has on the South African fresh orange industry. An inclusion of other export markets might be beneficial to discover trade diversion between export destinations.

\section{ENDNOTE}

1 The financial assistance of the National Research Foundation towards this research is hereby acknowledged.

\section{REFERENCES}

1 ANON. (1999) "Product Review: Citrus", AgriReview, October 1999, Standard Bank, Johannesburg, South Africa.

2 BOWER, J.P. (1999) Personal Communication, Professor of Horticulture, University of Natal, Pietermaritzburg, South Africa.

3 DE NEDERLANDSCHE BANK (2000) Exchange Rates, online information http:llwww dnb.nl.

4 DEPARTMENT OF TRADE AND INDUSTRY (1999) Agreement on Trade, Development and Co-operation, online information http://wwwdtipwr.gov,za.

5 EUROSTAT. Intra- and Extra-EU Trade (Monthly data - Combined Nomenclature), CD-ROM, Luxembourg, Luxembourg. Various issues.

6 FERREIRA, S.G. and VAN ZYL, J.L. (1997) "Gross Margins for Citrus Cultivars in Different Citrus Producing Areas", Citrus Journal, 7(2): 19 25.

7 FOOD AND AGRICULTURAL ORGANIZATION OF THE UNITED NATIONS (FAO) (1994) FAO Yearbook Trade vol. 47 1993, FAO, Rome, Italy.

8 HAUPTZOLLAMT KIEL (1999) Tariff Information, Kiel, F.R. of Germany.

9 HAYWARD-BUTT, P.R.N. and ORTMANN, G.F. (1994) "Demand Analysis of Oranges in South Africa", Agrekon, 33(3): 141-4.

10 HIGH PERFORMANCE SYTEMS (1997) Technical Documentation: STELLA Software, High Performance Inc., Hanover, United States of America. 
11 JOHNSON, P.R. (1971) Studies in the Demand for U.S. Exports of Agricultural Commodities, Economic Research Report No. 15, North Carolina State University, Raleigh, United States of America.

12 KHUELE, P.R.S. and DARROCH, M.A.G. (1997) "Demand and Supply Factors in the Export of South African Fresh Oranges to the United Kingdom: 1976-1993", Agrekon, 36(4): 542-60.

13 NEDCOR (1999) Economic comments: facts and forecasts of key economic variables, online information bitp://www nedcor.co.za.

14 SADIE, J.L., (1993) A Projection of the South African population, 19912011, Bureau of Market Research Report No. 196. University of South Africa, Pretoria, South Africa.

15 SCKOKAI, P. and MORO, D. (1996) "Direct Separability in MultiOutput Technologies: an Application to the Italian Agricultural Sector", European Review of Agricultural Economics, 23(1): 95-116.

16 SHEPHERD, G.S. (1972) Agricultural Price Analysis, $5^{\text {th }}$ ed. 1963, Revised printing 1972, The Iowa State University Press, Ames, United States of America.

17 SWINBANK, A. and RITSON, C. (1995) "The Impact of the GATT Agreement on EU Fruit and Vegetable Policy", Food Policy, 20(4): 33957. 